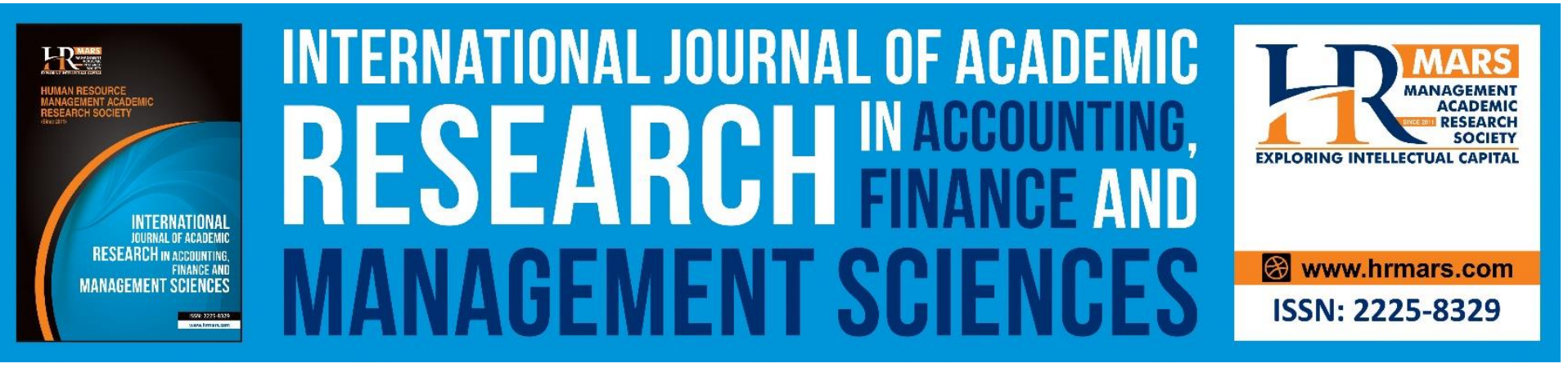

\title{
The Role of IILM in The Liquidity Risk Management of Islamic Banking Institutions
}

\section{Azlin Alisa Ahmad, Mohd Hafiz Safiai \& Nurun Nazirah Md Yusop}

To Link this Article: http://dx.doi.org/10.6007/IJARAFMS/v11-i3/11672 DOI:10.6007/IJARAFMS /v11-i3/11672

Received: 18 July 2021, Revised: 23 August 2021, Accepted: 09 September 2021

Published Online: 24 September 2021

In-Text Citation: (Ahmad et al., 2021)

To Cite this Article: Ahmad, A. A., Safiai, M. H., \& Yusop, N. N. M. (2021). The Role of IILM in The Liquidity Risk Management of Islamic Banking Institutions. International Journal of Academic Research in Accounting Finance and Management Sciences, 11(3), 762-771.

Copyright: (C) 2021 The Author(s)

Published by Human Resource Management Academic Research Society (www.hrmars.com)

This article is published under the Creative Commons Attribution (CC BY 4.0) license. Anyone may reproduce, distribute, translate and create derivative works of this article (for both commercial and non-commercial purposes), subject to full attribution to the original publication and authors. The full terms of this license may be seen at: http://creativecommons.org/licences/by/4.0/legalcode

Vol. 11, No. 3, 2021, Pg. 762 - 771

http://hrmars.com/index.php/pages/detail/IJARAFMS

JOURNAL HOMEPAGE

Full Terms \& Conditions of access and use can be found at http://hrmars.com/index.php/pages/detail/publication-ethics 


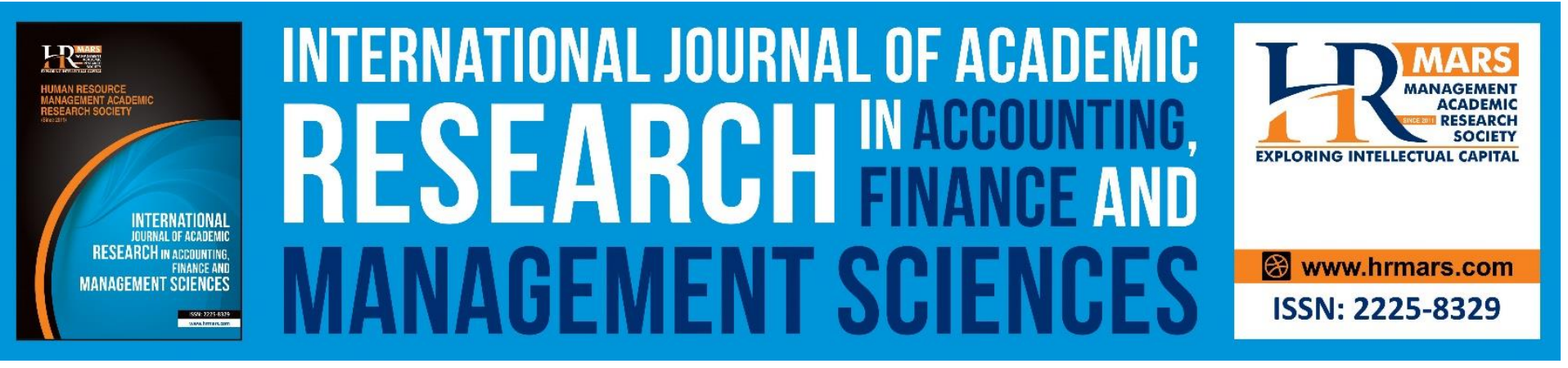

\title{
The Role of IILM in The Liquidity Risk Management of Islamic Banking Institutions
}

\author{
Azlin Alisa Ahmad, Mohd Hafiz Safiai \& Nurun Nazirah Md Yusop \\ Research Centre for Sharia, Faculty of Islamic Studies, Universiti Kebangsaan Malaysia
}

\begin{abstract}
Efficient and effective liquidity management is vital to Islamic banking institutions to prevent banks from running the risk of inability to meet deposit demands. However, banking institutions face a dilemma if they have excess liquidity funds but do not invest them in generating more profits. Consequently, establishing the International Islamic Liquidity Management Corporation (IILM) became necessary to address liquidity issues in Islamic banking institutions. Yet, there is still some ambiguity about the role played by IILM. Thus, this study aims to examine the role of IILM in the liquidity risk management of Islamic banking institutions. This qualitative study using a content analysis approach, while the data analysis method is descriptive. The study found that IILM plays a role in developing short-term liquidity instruments and acquiring the underlying assets. IILM also ensures that the instruments issued for Islamic banking liquidity risk management must comply with Shariah principles and support the development of Islamic liquidity management infrastructure by encouraging more efficient cross-border investment flows globally. IILM plays an essential role in improving liquidity risk management by issuing short-term sukuk instruments that benefit Islamic banking institutions.
\end{abstract}

Keywords: International Islamic Liquidity Management Corporation (IILM), Risk Management, Liquidity Risk, Islamic Banking.

\section{Introduction}

Liquidity is one of the crucial aspects in the management of banking institutions, either Islamic or conventional banking. Efficient and effective liquidity management will prevent the occurrence of liquidity risks that affect the management and performance of a banking institution due to the bank's inability to manage funds properly. The failure to manage funds properly will have a detrimental effect on the Islamic finance industry.

The establishment of the Islamic Liquidity Management Corporation (IILM) is an initiative taken by the regulatory authorities to further strengthen the development of Islamic liquidity management infrastructure in addressing the key issue Islamic financial institutions face, namely the lack of Shariah-compliant short -term liquidity instruments. The existence of IILM can assist Islamic banking institutions in managing their liquidity risk more efficiently. In addition, cross-border liquidity management is also improved through the issuance of high quality, liquid and Shariah-compliant IILM 
INTERNATIONAL JOURNAL OF ACADEMIC RESEARCH IN ACCOUNTING, FINANCE AND MANAGEMENT SCIENCES

Vol. 11, No. 3, 2021, E-ISSN: 2225-8329 ๑ 2021 HRMARS

sukuk instruments (Abdullah, 2010; Archer \& Rifaat, 2014; Bank Negara Malaysia, 2010a; Bello et al., 2017).

IILM has successfully issued its first short-term sukuk in August 2013 with a three-month maturity of USD 490 million. The amount continued to increase to US dollars 3 billon in 2016, indicating an increase in demand for IILM sukuk domestically and globally. This is also due to the increase in collateral assets for IILM with the increase in participating investors and allows IILM to increase the size of its sukuk issuance (Securities Commission Malaysia, 2020).

One of the typical known roles played by IILM is focusing on the issuance of investment instruments for liquidity management, for example IILM only receives excess liquidity funds from Islamic banking institutions who wish to subscribe for IILM sukuk issued for investment purposes. Due to the limited information and knowledge regarding IILM -issued sukuk, Islamic banking institutions in Indonesia, in particular, have not made IILM sukuk as their bank investment instrument (Nadia \& Rifki, 2018). Thus, this study will discuss the role of the International Islamic Liquidity Management (IILM) in improving the liquidity risk management of Islamic banking institutions.

\section{The Background of IILM}

The International Islamic Liquidity Management is a supranational organization established globally to further strengthen Islamic liquidity management infrastructure development in the face of the global financial crisis. The idea of establishing IILM arose due to the discussions of the High-Level Task Force on Liquidity Management in March 2009. The team was formed by the Islamic Financial Services Board Council (IFSB) (Bank Negara Malaysia, 2010a; Archer \& Rifaat, 2014).

As an international organization, IILM enjoys several privileges and grants immunity in its governance through an act passed by the Parliament of Malaysia, namely the International Islamic Liquidity Management Corporation Act 2011. The corporation is based in Malaysia and is headquartered in downtown Kuala Lumpur. The establishment of IILM aims to facilitate cross-border liquidity management among IIFS by offering a range of new Shariah-compliant and globally adopted instruments. IILM was also established to foster cooperation among the member countries involved to build a viable Islamic liquidity management infrastructure at the regional and international levels (Archer \& Rifaat, 2014; Bank Negara Malaysia, 2010a; Muljawan et al., 2014).

IILM successfully issued its first sukuk on 26 August 2013 worth USD 490 million with a maturity of three months and backed by the sovereign assets of the member countries involved. In fact, this sukuk has also been rated as A-1 by Standard and Poor's Rating Services and fully subscribed by its network of major distributors including two Islamic financial institutions from Malaysia namely Maybank Islamic Berhad and CIMB Islamic Bank Berhad (Archer \& Rifaat, 2014; Muljawan et al., 2014; Rizkiah, 2018). With the existence of short -term sukuk IILM is able to complement the existing medium and long -term sukuk in the market (IILM, 2015).

Over the past few years, the size of IILM's sukuk issuance programs in the market has increased from USD490 million to USD3.51 billion today for each of its issuance programs. This is driven by increasing market demand for high quality assets from Islamic financial institutions. This increase indicates the encouraging performance of IILM and the increase in the size of this amount is also due to the increase in collateral assets acquired for the issuance of IILM sukuk. IILM continues to play its role by issuing short -term liquidity instruments in the market to meet the needs of Islamic banking institutions in managing their excess liquidity. For 2019 alone, IILM sukuk issuances reached USD9 billion through its series of issuances for different maturities according to market demand and 
INTERNATIONAL JOURNAL OF ACADEMIC RESEARCH IN ACCOUNTING, FINANCE AND

MANAGEMENT SCIENCES

Vol. 11, No. 3, 2021, E-ISSN: 2225-8329 @ 2021 HRMARS

these sukuk issuances accounted for 26 per cent of the total global sukuk issuances in 2019 (IILM, 2020).

During the seven years of IILM's involvement in issuing short -term sukuk to meet IIFS's liquidity requirements, IILM has been selected to receive several awards domestically and internationally such as the Islamic Deal of the Year award on 29 May 2014 (The Asset) Outstanding Contribution to the Development of Islamic Liquidity Management Markets on 3 June 2015 (London Sukuk Summit Awards) and Best Cross-Border Sukuk Liquidity Provider on 24 May 2016 (The Asset). IILM has also successfully recorded 99 sukuk issuances since the inaugural issuance of IILM sukuk was issued in 2013 with a cumulative total of USD52 billion. These sukuk are issued with maturities of two weeks to six months to meet the short-term liquidity needs of Islamic banks. IILM sukuk can also be traded in the international market through platforms based in Asia, Europe and the Middle East such as the Gulf Cooperation Council (GCC) involving countries such as Bahrain, Kuwait, Oman, Qatar, Saudi Arabia and the United Arab Emirates (IILM, 2020).

\section{The Role of IILM in Enhancing the Efficiency of Liquid Risk Management of Islamic Banking Institutions}

International Islamic Liquidity Management Corporation Act 2011 defines IILM as a supranational organization established to improve liquidity risk management among institutions offering Islamic financial services (IIFS) especially Islamic banking institutions with the objective to: (a) facilitate cross -border liquidity management among IIFS by providing various Shariah -compliant liquidity instruments to meet IIFS liquidity requirements and (b) fostering regional and international cooperation more closely in supporting the development of a sound liquidity management infrastructure at the domestic, regional and international levels.

To achieve these objectives, IILM needs to play its role to address liquidity issues that arise among IIFS, especially Islamic banking institutions, through the issuance of new Shariah-compliant liquidity instruments. The developed instruments will be used by Islamic banks to improve their liquidity risk management at the domestic, regional and international levels. This means that the prominent role of IILM in enhancing the liquidity risk management of Islamic banking institutions is as follows:

\section{The Role of IILM in Developing New Shariah-Compliant Liquidity Instruments}

The role of IILM in developing shariah-compliant instruments can be divided into three, namely: (a) the role in creating short-term instruments; (b) the role of IILM in obtaining collateral assets; (c) the role in ensuring that the instruments issued comply with Shariah principles.

a. The role in creating short -term instruments

Short -term liquidity instruments are financial instruments traded in the money market that aim to increase the liquidity level of banking institutions. These financial instruments have a short maturity of between three months or less than one year. Usually, these instruments are easy to redeem, and their value does not change much when it reaches its maturity. Conventional banking institutions usually manage liquidity needs by using short-term debt securities such as treasury bills, commercial papers and banker's acceptance (Abdul Rahman, 1999).

These treasury bills are short-term debt securities issued by the government of a country; for example in the United States the maturity of these instruments is 30 days and 90 days. These instruments are widely used for liquidity management and they are sold at a discount and redeemed 
INTERNATIONAL JOURNAL OF ACADEMIC RESEARCH IN ACCOUNTING, FINANCE AND MANAGEMENT SCIENCES

Vol. 11, No. 3, 2021, E-ISSN: 2225-8329 @ 2021 HRMARS

at face value. These US treasury bills are also known as less risky instruments. However, these instruments cannot be used by Islamic banking institutions for liquidity management because there is an element of riba which is prohibited by shariah (Abdul Rahman, 1999).

As these US treasury bills do not comply with Shariah principles, IILM has taken the initiative by creating short-term sukuk to meet the liquidity needs of Islamic banks at the domestic, regional and international levels (Najibah \& Kamaruzaman, 2018a). IILM has also played a key role in addressing the issue of lack of liquidity instruments in the Islamic money market, by taking the approach of creating new liquidity instruments that can help Islamic banking institutions address the excess liquidity they face. With the issuance of this IILM sukuk, further diversification of shariah compliant short term liquidity instruments in the Islamic money market. This gives an advantage to Islamic banking institutions because they have a variety of options in choosing the appropriate liquidity instruments for the investment of their liquidity funds thus being able to generate profits at the maximum level.

For this short term sukuk issuance, IILM uses Asset Backed Commercial Paper (ABCP) as a model in the structuring of IILM sukuk issuance. In western European and American countries, ABCP is a short-term financial instrument with maturities ranging from 90 days to 270 days used to manage liquidity. Usually, these instruments are issued by banks or finance companies based on the institution's physical assets and used for short-term financing purposes, but these instruments are not widely used by countries that offer Islamic banking systems (Archer \& Rifaat, 2014).

Although IILM as an institution that issues sukuk is not rated by any credit rating agency, the short-term sukuk program issued by IILM is rated and given an A-1 rating by Standard and Poor's Rating Services. IILM issues sukuk with maturities of less than one year as IILM only offers short -term liquidity instruments for liquidity management among IIFS. This coincides with the fulfilment objective of IILM to meet the liquidity needs of IIFS, especially Islamic banking institutions internationally (Archer \& Rifaat, 2014).

IILM Sukuk is issued every three months to ensure that IILM receives deposits at low market prices from investors and IILM does not have to pay a profit rate to investors with high value. In addition, with the issuance of short -term sukuk, it will be easier for Islamic banking institutions to invest in short -term financial instruments, thus generating maximum profits. This is because, one of the main sources of banks obtaining their liquidity funds is through deposits from customers who only have a short period of time for the bank to carry out investment activities (Najibah \& Kamaruzaman, 2018b).

b. The role of IILM in obtaining collateral assets

The underlying asset is one of the important elements in the structuring of a sukuk. This is because sukuk is a financial instrument based on sharia compliant assets and the profit yield of sukuk issued depends on the underlying asset. In the IILM sukuk issuance process, the underlying assets used must be 51 percent tangible assets such as buildings, land, etc. and another 49 percent are non-tangible assets, for example assets that cannot be clearly seen but have value such as copyright, financial assets etc.

Based on the provisions of Article 5 Agreement, among the roles of IILM is to collect assets from each shareholder or central bank of member countries participating in IILM including the Islamic Corporation for the Development of the Private Sector which is a multilateral development institution. As for the assets involved not only from the assets owned by the central bank but it also involves the assets of the country (Najibah \& Kamaruzaman, 2018a). 
INTERNATIONAL JOURNAL OF ACADEMIC RESEARCH IN ACCOUNTING, FINANCE AND MANAGEMENT SCIENCES

Vol. 11, No. 3, 2021, E-ISSN: 2225-8329 @ 2021 HRMARS

The assets that have been collected are placed in a pool of assets that is accountable to the SPV appointed by IILM, namely BNP Paribas Securities and Services. Then the assets involved are valued as a whole and the amount obtained is used as the underlying asset for the issuance of IILM sukuk on a regular basis. The governing board of IILM has stipulated that the underlying assets for sukuk issuance must be sovereign or quasi sovereign assets of member states and supranational organizations that are shareholders of IILM (Archer \& Rifaat, 2014; Bello et al., 2017).

The underlying assets must also comply with the principles outlined by sharia, this means that assets used to carry out Shariah non -compliant activities cannot be used as collateral assets for the issuance of sukuk. Close cooperation and commitment between the central banks of member countries is crucial for the issuance of sukuk, as each series of sukuk to be issued depends on the underlying assets received by IILM shareholders (Archer \& Rifaat, 2014; Muljawan et al., 2014; Najibah \& Kamaruzaman, 2018a).

As the issue raised by Rizkiah (2018) who stated that sukuk issued by IILM faces Shariah issues related to the underlying assets used for sukuk issuance. This is because the investor does not know clearly about the asset, this situation leads to the occurrence of an element of gharar (uncertainty) in the ijārah contract. Whereas in the ijārah contract, it is stated that among the asset conditions that must be complied with is that the ijārah asset must be clearly defined. If the conditions regarding the ijārah asset cannot be resolved, let alone the ownership status of the asset that should have belonged to the sukuk holder will also not be implemented.

However, based on a study conducted by Archer and Rifaat (2014); Muljawan et al (2014) as well as Najibah and Kamaruzaman (2018b), clearly state that IILM uses a wakālah contract structure in its short term sukuk issuance process. This is because, according to Archer and Rifaat (2014) the concept of wakālah applied in the process of issuing IILM sukuk involves two SPVs who act as representatives in performing their respective duties. BNP Paribas Securities and Services which is an SPV appointed as a representative in holding the pool of assets collected by IILM. While IILM will also act as a representative to issue sukuk that will provide cash flow to investors.

According to Najibah and Kamaruzaman (2018b) the use of wakālah contracts in the structuring of IILM sukuk is also the best way that will further facilitate the issuance of IILM sukuk. This is because wakālah contracts can combine the use of tangible and non-tangible assets for the issuance of sukuk and to resolve the issue of shortage of underlying assets faced by IILM. The wakālah contract is seen as more flexible than the ijārah contract because in the ijārah contract, the assets used must be assets or goods that are eligible for rent only. Furthermore, the use of wakālah contracts will reduce the reliance on tangible assets for the issuance of IILM sukuk.

Sukuk holders or investors generally do not want the underlying asset, instead, investors only look at the profit that will be obtained from the underlying asset. At the same time investors need more cash flow to meet their short-term liquidity. The sukuk issuer, for example IILM or the original owner of the asset (asset contributing countries), rationally does not intend to sell or hand over its assets to the sukuk holder, instead the sukuk issuer only agrees to give temporary ownership to the sukuk holder by taking advantage or profit from the underlying asset (Islamic Interbank Money Market, n.d.).

Apart from the responsibility of procuring assets, IILM also needs to identify assets contributed by member countries with high ratings as outlined by Basel III and IILM itself. This is to ensure that the sukuk instruments issued by IILM are of high quality and liquid. The underlying assets will be held by the SPV until maturity and will not be traded based on the agreement reached by both 
INTERNATIONAL JOURNAL OF ACADEMIC RESEARCH IN ACCOUNTING, FINANCE AND

MANAGEMENT SCIENCES

Vol. 11, No. 3, 2021, E-ISSN: 2225-8329 @ 2021 HRMARS

parties (Archer \& Rifaat, 2014; Najibah \& Kamaruzaman, 2018a). Currently, IILM can issue highquality sukuk and has been rated A-1 by Standard and Poor's Rating Services. The underlying assets for IILM issued sukuk also meet the high quality liquid asset standards (HQLA) set by Basel III to meet the liquidity risk management of Islamic banking institutions. The role that IILM has played can also help Islamic banking institutions to address the challenges in meeting the liquidity requirements provided in Basel III.

c. The role in ensuring that the instruments issued comply with Shariah principles

Most of the Islamic financial institutions globally faced liquidity risk management issues due to the lack of shariah -compliant short -term liquidity instruments in the market. This causes most Islamic banking institutions to have a large cash surplus and the holding assets of the institutions are not profitable and get low returns (Bank Negara Malaysia, 2010a; Raudhah \& Abdul Ghafar, 2013; Ramadhan \& Nasir, 2014).

Thus, IILM seeks to improve the liquidity management of Islamic banking institutions through the issuance of Shariah-compliant short-term sukuk instruments to help Islamic banks overcome their liquidity risk. Profit generation through the fund's investment in IILM sukuk also has the potential to provide high returns, as IILM-issued sukuk is rated A-1 and complies with widely adopted Shariah principles thus improving the efficiency of cross-border liquidity management between banking and Islamic financial institutions at the international level.

Sukuk issued by IILM does not follow any guidelines including the guidelines provided by AAOFI, this is because IILM has its own Shariah Advisory Committee that will monitor and ensure that the principles and processes of issuing IILM sukuk comply with Shariah requirements. (Bank Negara Malaysia, 2010a; Najibah \& Kamaruzaman, 2018a; Ramadhan \& Nasir, 2014). However, this does not mean that IILM sukuk cannot be widely marketed globally because it does not follow AAOFI guidelines. This is because some member countries do not adopt the AAOFI guidelines, such as Qatar and Indonesia. Shariah Advisers who evaluate IILM sukuk are also appointed by IILM's own shareholders comprising of qualified and extensively experienced Islamic financial experts from member countries such as Saudi Arabia, Malaysia, Nigeria and Kuwait (Najibah \& Kamaruzaman, 2018a).

In performing its role in developing short -term liquidity instruments, IILM also ensures that instruments issued for Islamic banking liquidity risk management must comply with Shariah principles. By carrying out this role, Shariah issues that are disputed by Islamic scholars in search instruments such as the concepts of baý al-dayn and baý al-inah can be addressed by IILM. This is because the structuring of sukuk issued by IILM is based on the concept of wakālah which is widely adopted globally.

The concept of wakālah is an agency contract that involves one party giving a mandate to another party as a representative to perform certain tasks. The application of the wakālah principle used in this sukuk involves two special purpose vehicles (SPV) which makes IILM act as SPV in issuing sukuk and also a representative in collecting the underlying assets as well as BNP Paribas Security Services appointed by IILM as the representative entrusted to hold the assets (Archer \& Rifaat, 2014; Bello et al., 2017; Ramadhan \& Nasir, 2014).

\section{The Role of IILM in Developing Islamic Liquidity Management Infrastructure}

Islamic banking institutions need shariah -compliant liquidity instruments to manage their liquidity by generating income through investments in short -term instruments for profit. Among the liquidity 
INTERNATIONAL JOURNAL OF ACADEMIC RESEARCH IN ACCOUNTING, FINANCE AND MANAGEMENT SCIENCES

Vol. 11, No. 3, 2021, E-ISSN: 2225-8329 @ 2021 HRMARS

instruments that Islamic banks often use for liquidity risk management such as commodity murābahah, wakālah investment, sukuk ijārah or salām and so on. However, there are constraints faced by Islamic banking institutions in generating short -term liquidity funds as a result of the lack of shariah -compliant short -term liquidity instruments in the market. Existing liquidity instruments also face acceptance problems in the international Islamic financial market as interbank transactions are relatively limited. Futhermore, Shariah instruments introduced also lack uniformity and differ between countries (Alfisyahrin, 2014; Rizkiah, 2018).

Therefore, the short-term sukuk offering from IILM can assist Islamic banking institutions at the domestic, regional and international levels in improving their liquidity risk management more efficiently and effectively. In addition to IILM's role in developing shariah-compliant liquidity instruments and meeting the liquidity needs of Islamic banking institutions, IILM also supports the development of Islamic liquidity management infrastructure by promoting more efficient crossborder investment flows globally. This is because IILM-issued sukuk uses the wakālah principle in its structuring and is adopted internationally especially in the Middle East and is dominated by the US dollar which further facilitates transactions between Islamic banks (Bank Negara Malaysia, 2010a; Muljawan et al., 2014; Rizkiah, 2018).

IILM plays a vital role in developing the Islamic liquidity management infrastructure. At the same time IILM also activates the Islamic money market by offering shariah -compliant short -term liquidity instruments that can be traded in the international money market. The initiative taken by IILM can resolve the issue of inactive Islamic money market for Islamic banking institutions such as in Sudan for example or other countries where their Islamic money market is inactive. Furthermore, this initiative also helps create a specific Islamic liquidity management platform for countries like Nigeria where Islamic banking institutions do not have a platform to manage their bank liquidity effectively. The existence of a globally marketable offering of shariah -compliant liquidity instruments will facilitate cross -border Islamic liquidity management and provide opportunities for investors to conduct sukuk transactions between Islamic banking institutions from various countries.

Over the past few years, the amount size for the IILM sukuk issuance program has shown an increase with amounts starting from USD 490 million in 2013 increasing to USD 3.51 billion in September 2020 with sukuk maturity offerings varying from one month, three months and six months. As a result of the increase in the size of the amount to meet the liquidity needs of Islamic banks, IILM has successfully increased the number of participating investors. The major distributor network for IILM sukuk has successfully activated the secondary market by conducting sukuk buying and selling transactions to other investors interested in investing, with a turnover of around USD 212 million in the first quarter of 2020. Despite the current worsening economic situation with the fall in world oil prices in the first quarter of 2020, IILM remains committed to offering its services by reissuing additional subscriptions of USD 1.6 billion due to the encouraging response from investors (IILM, 2020).

Furthermore, in accordance with the provisions in Article 5 of the Agreement, IILM also provides advisory services and technical support in the development and management of Islamic liquidity among Islamic banking institutions and member countries. This will help create a conducive environment to foster the integration of regional and global Islamic financial markets (Bank Negara Malaysia, 2010b). In addition, IILM has also organized seminars and discussions with international financial agencies to obtain views and solutions on liquidity management issues at the global level. In 2013 and 2014, IILM with Thomson Reuters organized two roundtable discussions on Shariah issues 
INTERNATIONAL JOURNAL OF ACADEMIC RESEARCH IN ACCOUNTING, FINANCE AND

MANAGEMENT SCIENCES

Vol. 11, No. 3, 2021, E-ISSN: 2225-8329 @ 2021 HRMARS

and IILM also collaborated with international regulatory bodies such as the IFSB and IIFM in organizing seminars on Islamic capital markets on 13 November 2018 at Abu Dhabi. The seminar was organized with the objective to strengthen further the economic development and resilience of the Islamic financial sector at the international level (IFSB, 2018).

\section{Conclusion}

To conclude, the role that IILM has played in improving the liquidity risk management of Islamic banking institutions can indirectly resolve the issue of lack of short -term liquidity instruments that comply with Shariah principles in the market. The sequence of the establishment of the International Islamic Liquidity Management Corporation (IILM) can further strengthen the robust, Islamic liquidity management infrastructure at the domestic and international levels. IILM has also improved cross border liquidity management among IIFS (institutions offering Islamic financial services) through the issuance of short -term liquidity instruments that comply with Shariah principles. With the issuance of this IILM sukuk will further increase the number of short -term liquidity instruments in the market and can provide an opportunity for investors to diversify their liquid asset portfolio. Similarly, IILM seeks to improve cross-border liquidity management by internationally strengthening the Islamic liquidity management infrastructure through cooperation between member countries' central banks. In addition, Islamic banking institutions also have the opportunity to conduct IILM sukuk transactions in the secondary market with investors from various countries.

\section{References}

Abdullah, D. V. (2010). Liquidity Management in Institutions Offering Islamic Financial Services. Second Islamic Financial Stability Forum. Kingdom of Saudi Arabia: Jeddah. file://C:/Users/MyPC/Downloads/Liquidity\%20Management\%20in\%20Insitutions\%200fferin g\%20lslamic\%20Financial\%20Services_En.pdf [2017, April 12].

Abdul Rahman, Y. (1999). Islamic Instruments for Managing Liquidity. International Journal of Islamic Financial Services 1(1), 11-17.

Alfisyahrin, A. J. (2014). Pembangunan Instrumen Kecairan Baru Yang Patuh Syariah. Muzakarah Penasihat Syariah Kewangan Islam Kali Ke-9, Kuala Lumpur Islamic Finance Forum (KLIFF), November 10.

Archer, S., \& Rifaat, A. A. (2014). The IILM Short-Term Sukūk for Liquidity Management: A Success Story in Enhancing Financial Stability. SEACEN Financial Stability Journal 3(1), 11-23. https://www.seacen.org/publications/RePEc/702001-100356-PDF.pdf [2017, April 17].

Bank Negara Malaysia. (2010a). Laporan Kestabilan Kewangan Dan Sistem Pembayaran.http://www.bnm.gov.my/files/publication/fsps/bm/2010/fs2010_buku.pdf [2016, December 21].

Bank Negara Malaysia. (2010b). Resolusi Syariah dalam Kewangan Islam. Ed. ke-2 https://www.bnm.gov.my/files/press_release/2010/shariah_resolutions_2nd_edition.pdf [2020, September 11].

Bello, N., Hasan, A., \& Saiti, B. (2017). The Mitigation of Liquidity Risk in Islamic Banking Operations. Banks \& Bank Systems 12(3), 154-165.

International Islamic Liquidity Management (IILM). (2020). International Islamic Liquidity Management Corporation. https://iilm.com/about-iilm/ [2016, December 21].

Islamic Financial Services Board (IFSB). (2018). Press Release. 
INTERNATIONAL JOURNAL OF ACADEMIC RESEARCH IN ACCOUNTING, FINANCE AND

MANAGEMENT SCIENCES

Vol. 11, No. 3, 2021, E-ISSN: 2225-8329 @ 2021 HRMARS

https://www.ifsb.org/press_full.php?id=448\&submit=more [2019, January 15].

Islamic Interbank Money Market. (n.d). Jenis Instrumen dalam Pasaran Wang Antara Bank Secara Islam. https://iimm.bnm.gov.my/index.php?ch=4\&pg=4\&ac=22\#12 [Oktober 2020].

Raudhah, M. A. H., \& Abdul Ghafar, I. (2013). Keperluan Kecairan Jangka Pendek di Perbankan Islam Melalui Keterkaitan Komoditi. Prosiding Persidangan Kebangsaan Ekonomi Malaysia ke VIII, Jil. 1, pp. 426-437.

Muhd. Ramadhan, F. E., \& Nasir, M. H. (2014). Pembangunan Produk-Produk Kecairan Baru Yang Berkualiti Tinggi Yang Patuh Syariah. Muzakarah Penasihat Syariah Kewangan Islam Kali Ke-9, Kuala Lumpur Islamic Finance Forum (KLIFF), November 10.

Muljawan, D., Yumanita, D., Taruna, A. A., \& Astuti, R. I. (2014). Penggunaan Sukuk IILM Sebagai Instrumen Investasi Dan Likuiditas Perbankan Syariah. Working Paper WP/ 7 /2014. https://adoc.tips/penggunaan-sukuk-iilm-sebagai-instrumen-investasi-dan-likuid.html [2018, Januari 12].

Nadia, U., \& Rifki, I. (2018). Keputusan Investasi Perbankan Nasional Pada Sukuk International Islamic Liquidity Management (IILM). Jurnal Riset Manajemen Sekolah Tinggi Ilmu Ekonomi Widya Wiwaha Program Magister Manajemen 5(1), 43-55.

Najibah K. S., \& Kamaruzaman, N. (2018a). Pengurusan Kecairan Institusi Kewangan Islam (IKI) Di Malaysia: Analisis Perbandingan Antara Keperluan International Islamic Liquidity Management (IILM) Berbanding Pasaran Wang Antara Bank secara Islam (IIMM). International Journal of Islamic and Civilizational Studies UMRAN 5(1), 01-18.

Najibah, K. S., \& Kamaruzaman, N. (2018b). Analisis Terhadap Aset Sandaran Alternatif bagi Penerbitan Sukuk Jangka Pendek oleh International Islamic Liquidity Management (IILM). Jurnal Pengurusan 54, 181-188.

Rizkiah, S. K. (2018). Liquidity Management in Islamic Banking: Issues and Challenges. Tazkia Islamic Finance and Business Review 12(2), 131-152.

Securities Commission Malaysia. (2020). Resolutions of the Shariah Advisory Council of the Securities Commission Malaysia. Kuala Lumpur: Bukit Kiara. 